\title{
Assessment of municipal wastewater genotoxicity using the Ames fluctuation test, the SOS Chromotest and the mussel micronucleus test: a comparison
}

\author{
Bettina Eck-Varanka, Nora Kováts, Gábor Paulovits and Eszter Horváth
}

\begin{abstract}
Municipal wastewaters may contain a variety of genotoxic compounds, including drugs or their metabolites, PAHs, etc. Bacterial genotoxicity assays use DNA impairment as end point while micronucleus tests, conducted on eucaryotes, assess chromosome aberrations. As relatively few comparative studies exist, in this study results of the micronucleus test using the painter's mussel (Unio pictorum) are compared to those of two bacterial assays, the Ames test and the SOS Chromotest. Both the Ames test and the micronucleus test showed clear concentration-response pattern, however, the Ames test proved more sensitive. Of the two bacterial assays, the SOS Chromotest gave positive result only for the most concentrated sample.
\end{abstract}

Keywords-municipal wastewater, genotoxicity, mussel micronucleus test, Ames test, SOS Chromotest

\section{Introduction}

In municipal wastewaters, most often drug residues and/or their metabolites might exert genotoxic effect [1]. Another potentially genotoxic group of chemicals are polycyclic aromatic hydrocarbons (PAHs), in areas where rainwater and municipal wastewater are collected together (as rainwater might wash PAHs from the roads) [2]. The monitoring of the occurrence of genotoxic compounds might require rather costly analytics, especially in case of drug residues. Genotoxicity bioassays, on the other hand, are estimating the aggregate genotoxicity of the sample and might be relatively cost-effective. These tests cover assays on different taxonomic levels: prokaryotes (bacterial tests) and eukaryotes (most often micronucleus test). Bacterial tests include, among others, the SOS Chromotest [3], and the reverse mutation Ames test.

Bettina Eck-Varanka

University of Pannonia, Institute of Environmental Sciences Hungary

Nora Kováts (Corresponding author)

University of Pannonia, Institute of Environmental Sciences Hungary

Gábor Paulovits

MTA Centre for Ecological Research, Balaton Limnological Institute Hungary

Eszter Horváth

University of Pannonia, Institute of Environmental Sciences Hungary
The SOS Chromotest is a short-term, enzymatic colorimetric assay for the detection of the presence of genotoxic compounds using Escherichia coli PQ 37 strain. The SOS system is a complex, DNA-damage activated response under the regulation of the SOS promoter. In $E$. coli $\mathrm{PQ} 37$ the only functioning b-galactosidase gene (lac Z) is fused to the bacterial sfiA SOS operon. Thus, SOS response initiates lac $Z$ transcription, and b-galactosidase activity is detected spectrophotometrically by the addition of $\mathrm{X}$-gal (5-bromo-4-chloro-3-indolyl- $\beta$-D-galactopyranoside) [4].

The Ames bacterial reverse mutation assay applies genetically engineered strains of Salmonella typhimurium. The method is based on the chemical triggered reversion of histidine producing ability of the strains, enabling them to grow on histidine free medium. Several different methods have been developed, including the plate incorporation assay, the preincubation method, and the fluctuation test [5] [6] [7]. Both tests have been widely applied for detecting genotoxicity in wastewater samples [8] [9].

The micronucleus test has been used for assessing the genotoxicity of individual compounds or complex environmental matrices since the 1980's [10]. MN formation indicates mitotic chromosome breakage or chromosome mis-segregation [11]. Several studies use mussel MN test: though this has not been standardized yet, well described, step-by-step test protocols are available [11] [12]. Mussels are sedentary, filter-feeding organisms, and have proven sensitive for a wide range of environmental contaminants. In addition to laboratory experiments, they can be used in situ, for detecting mutagen compounds in surface waters [13] [14].

As bacterial tests and the micronucleus test represent (1) different taxonomic levels (prokaryotes vs. eukaryotes) and different end points (DNA vs. chromosomal damage), in this study the sensitivity of the mussel micronucleus test is evaluated in comparison with two bacterial tests, the Ames fluctuation test and the SOS Chromotest, using pre-treated municipal wastewater.

\section{Materials and methods}

Raw wastewater sample was collected from the municipal treatment plant of Veszprém. Capacity of the plant is $12000 \mathrm{~m}^{3} /$ day. The micronucleus test was initiated directly after sampling. The sample was kept at $-18^{\circ} \mathrm{C}$ until the bacterial tests were performed. 


\section{A. Test organisms}

Unio pictorum specimens were collected from Lake Balaton and were kept in a flow-through aquarium. Water source was Lake Balaton water, therefore not only proper oxygenation was ensured but a constant food supply as well. Animals were acclimatized for 4 weeks prior to testing $\left(\mathrm{t}=18-24^{\circ} \mathrm{C}, \mathrm{DO}=85-93 \%\right)$.

\section{B. Test conditions and treatment}

The assay was performed based on the protocol described by Wozniczki et al (2004), with some modifications. U. pictorum specimens with length of $5-8 \mathrm{~cm}$ were used. Treatments were performed in 3 replicates. For each concentration as well as for the controls, aquaria of 31 volume were used. Aquaria were aerated during the experiment, temperature was set at $22{ }^{\circ} \mathrm{C}$. Exposure time was 4 days. Dilution series was set as follows: 10x, 20x, 30x and 40x dilution. For dilution, as well as for the control, Lake Balaton water was used. Considering the fact that municipal wastewater contains degradable organic compounds, a semi-static test was conducted, that is, test solution was changed in the middle of the test, after 2 days.

\section{Micronucleus test}

After 4 days, haemolymph was taken from the posterior adductor muscle using the non-lethal technique described by Gustafson et al (2005). $1 \mathrm{ml}$ of haemolymph was mixed with $0.3 \mathrm{ml} 10 \%$ acetic acid in methanol as a fixative and centrifuged at $1000 \mathrm{rpm}$ for 5 minutes. The supernatant was discarded and the rest was fixed in $1 \mathrm{ml} 80 \%$ ethanol. In this way the sample can be kept refrigerated for several weeks. For processing the samples, refrigerated samples were centrifuged again at $1000 \mathrm{rpm}$ for 5 minutes. The supernatant was discarded, the pellet which contained the cells in a more concentrated form, was smeared onto a microscope slide and allowed to dry. After that the slides were fixed in $80 \%$ methanol, air dried and stained with $5 \%$ Giemsa in distilled water for 20 minutes. [15]

Photos were taken by a Zeiss AxioScope A1 microscope with an AxioCam ICC1 camera and Zen 2011 program at 400x magnification. Micronuclei were identified according to Fenech (1992) [16]. For each animal 250 cells were counted. One-way ANOVA with Tukey post hoc test was used to compare the mean $\mathrm{MN}$ numbers between the treatments.

\section{SOS Chromotest}

For SOS Chromotest the SOS Chromotest TM kit (EBPI - Environmental Bio-detection Products Inc.) was used according to the manufacturer's instructions, and in compliance with the OECD guidelines No 471:1977. The absorbance of samples was detected on 615 and $405 \mathrm{~nm}$ with DiareaderELx800 ELISA device. The SOS repair system induction was measured by the calculation of induction factor (IF) and induction potential (SOSIP) according to Krifaton (2012). Samples with 1.5 or higher IF were considered genotoxic [17].

\section{E. Ames test}

The fluctuation Ames test was performed according to Hubbard (1984) with slight modification [18]. Shortly:
Salmonella typhimurium TA100 cells were precultured overnight in nutrient broth (Oxoid) on $37^{\circ} \mathrm{C}$. Cells were washed twice in Davis minimal medium $\left(67.4 \mathrm{mM} \mathrm{PO}_{4}{ }^{3-}\right.$, $8.38 \mathrm{mM} \mathrm{SO}_{4}{ }^{2-}, 15.1 \mathrm{mM} \mathrm{NH}_{4}^{+}, 5.1 \mathrm{mM} \mathrm{Na}^{+}, 98.1 \mathrm{mM} \mathrm{K}^{+}$, $0.83 \mathrm{mM} \mathrm{Mg}^{2+}, 1.7 \mathrm{mM}$ citrate, $139 \mu \mathrm{M}$ glucose $10 \mu \mathrm{g} / \mathrm{ml}$ histidine, $0.1 \mathrm{mg} / \mathrm{ml} \mathrm{D}$-biotin) and cell number was adjusted to $10^{*} 10^{5}$ cells $/ \mathrm{ml}$. Samples were distributed in $200 \mu \mathrm{l}$ volumes to 96 well microplates. Cell free control, a solvent free negative control, and a positive control with $0.5 \mu \mathrm{g} / \mathrm{ml}$ concentration sodium-azide were also applied. Plates were incubated in humid chamber for 72 hours in $37^{\circ} \mathrm{C}$. On the day of evaluation $20 \mu \mathrm{l}$ of $2 \mathrm{mg} / \mathrm{ml}$ concentration bromcresolpurple (aqueous) solution was added to each sample. Purple colour signified negative, yellow positive (cell growth) result. Intermediate shades were regarded positive. The experiment was also performed with S9 activation, in which case $10 \mathrm{ml}$ suspension contained $2.5 \mathrm{ml}$ S9 mix (EBPI) assembled according to the producers guide (S9 activation simulates metabolic processes in the liver of higher organisms). For positive control 2-amino-antracene was used in $100 \mu \mathrm{g} / \mathrm{ml}$ concentration. For the evaluation of mutagenic effect the $\chi^{2}$ test was applied with $95 \%$ confidence level [19].

\section{Results and Discussion}

Genotoxic response is expressed as number of micronuclei/250 cells in case of the mussel micronucleus test, percentage of positive wells in case of the Ames test and IF value in case of the SOS Chromotest. Fig. 1. shows results of the micronucleus test. Genotoxic response was already observed in the lowest concentration (40x dilution) and a clear concentration-response curve was given.

Fig. 2. shows the results of the Ames test, with S9 activation. Here the lowest concentration (40x dilution) already gave a significant positive response. The $10 \mathrm{x}$ and 20x dilutions do not seem genotoxic: however, in these concentrations cytotoxic effect appeared, killing the test bacteria. Without $\mathrm{S} 9$ activation, no genotoxic effect could be observed. In case of the SOS Chromotest, only the highest concentration gave positive response, after $\mathrm{S} 9$ activation.

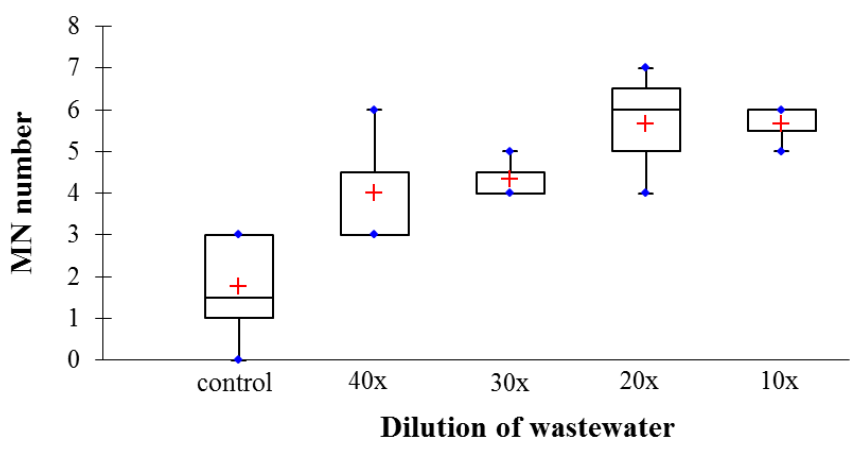

Figure 1. Unio pictorum micronucleus numbers (expressed as $\mathrm{MN} / 250$ cells) 


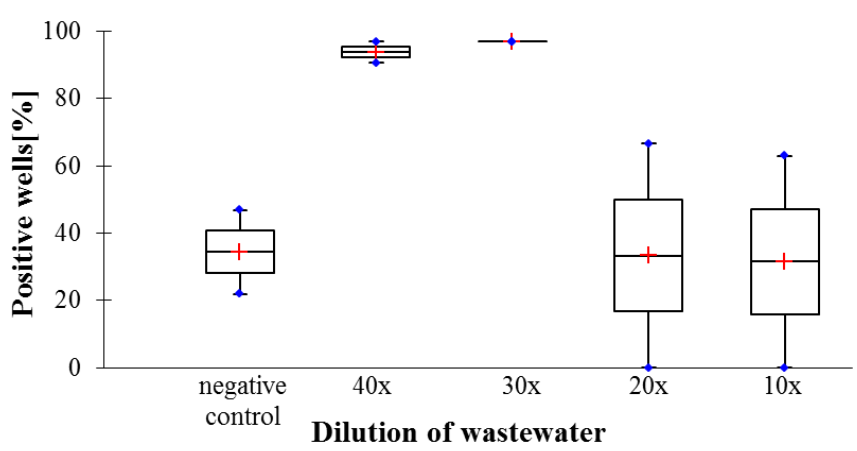

Figure 2. Ratio of positive wells in the Ames test (\%)

Several reports are available to compare the sensitivity of the Ames test and SOS Chromotest. Isidori et al. (2006) assessed the genotoxic effect of the pharmaceuticals Furosemide and its photoproduct and found that while these compounds proved negative in the SOS Chromotest, a variability among the mutagenic responses was observed in the Salmonella mutagenicity assay [20]. The Ames test proved more sensitive than the SOS Chromotest for detecting genotoxicity in hospital wastewaters [21] and in municipal wastewaters [22].

Results of the present study are in concordance with literature data: with S9 activation, the Ames fluctuation test gave the highest response, showing cytotoxicity in the $10 \mathrm{x}$ and 20x dilutions, and maximum genotoxic response in the 40x dilution. The SOS Chromotest gave positive response only in the highest concentration (10x dilution), also after S9 activation.

Relatively few reports are available on the comparison of the micronucleus test and bacterial genotoxicity assays. Monarca et al. (2004) applied a complex battery to evaluate the genotoxicity of disinfected drinking water. They found that while none of the bacterial tests gave positive answer, the mollusc micronucleus test was able to detect genotoxicity in raw water (in their study, Dreissena polymorpha was employed) [23].

However, as bacterial genotoxicity assays detect DNA aberration and the MN test detects chromosomal damage, the genotoxic risk screened by the bacterial tests does not necessarily overlap with the MN test results [24]. The same authors therefore suggest the application of both the MN test and a bacterial test. In their study, however, a flowcytometry based MN test was used, which significantly increases effort and cost of the test.

\section{Conclusions}

Based on our results, it can be also suggested that for the characterisation of a wastewater sample, the two sensitive tests, Ames test and the micronucleus test should be performed in parallel. However, taking into consideration the methodological constraints of the micronucleus test (relatively long exposure which requires the renewal of the sample and also, the assay needs relatively expensive equipment), for screening purposes the Ames test seems sufficient.

\section{Acknowledgments}

We acknowledge the financial support of the Hungarian State and European Union under the

TÁMOP-4.2.2.B-15/1/KONV-2015-0004 project.

\section{References}

[1] K. Kümmerer,A. Al-Ahmad and V. Mersch-Sundermann, "Biodegradability of some antibiotics, elimination of the genotoxicity and affection of wastewater bacteria in a simple test," Chemosphere, vol. 40, pp. 701-710, 2000.

[2] P. A. White and J. B. Rasmussen, "The genotoxic hazards of domestic wastes in surface waters," Mut. Res. vol. 410, pp. 223-236, 1998.

[3] OECD Guidelines No 471:1977 - Bacterial Reverse Mutation Test

[4] P. Quillardet and M. Hofnung, "The SOS Chromotest, a colorimetric bacterial assay for genotoxins: procedures," Mut. Res. vol. 147, pp. 65-78, 1985.

[5] B. N Ames, F. D. Lee and W. E. Durston, "An Improved Bacterial Test System for the Detection and Classification of Mutagens and Carcinogens," Proc. Nat. Acad. Sci. USA, vol. 70(3), pp. 782-786, 1973.

[6] K. Mortelmans and E. Zeiger, "The Ames Salmonella/microsome mutagenicity assay," Mut. Res. vol. 455, pp. 29-60, 2000.

[7] S. Jomini, J. Labille, P. Bauda and C. Pagnout, "Modifications of the bacterial reverse mutation test reveals mutagenicity of $\mathrm{TiO}_{2}$ nanoparticles and byproducts from a sunscreen $\mathrm{TiO}_{2}$-based nanocomposite,” Toxicol. Lett. vol. 215, pp. 54-61, 2012.

[8] R. Denkhaus, W. O. K.Grabow and O. W. Prozesky, "Removal of mutagenic compounds in a wastewater reclamation system evaluated by means of the Ames Salmonella/microsome assay," Water Sci. Technol. vol. 13, pp. 571-589, 1981 .

[9] A. Kamiya and Y. Ose, "Study of the behaviour of mutagens in wastewater and emission gas from a municipal incinerator evaluated by means of the ames assay," Sci. Total Environ. vol. 65, pp. 109120, 1987.

[10] R. K. Das and N. K. Nanda, "Induction of micronuclei in peripheral erythrocytes of fish Heteropneustes fossilis by mitomycin $\mathrm{C}$ and paper mill effluent," Mut. Res. vol. 175, pp. 67-71, 1986.

[11] C. Bolognesi and M. Fenech, "Mussel micronucleus cytome assay," Nat.Protoc. vol. 7(6), pp. 1125-1137, 2012.

[12] P. Woźnicki, R. Lewandowska, P. Brzuzan, E. Ziomek and R. Bardega,'The level of DNA damage and the frequency of micronuclei in haemolymph of freshwater mussels Anodonta woodiana exposed to benzo[a]pyrene," Acta Toxicol. vol. 12(1), pp. 41-45, 2004.

[13] P. Guidi, G. Frenzilli, B. Benedetti, M. Bernardeschi, A. Falleni, D. Fattorini, F. Regoli, V. Scarcelli and M. Nigro, "Antioxidant, genotoxic and lysosomal biomarkers in the freshwater bivalve (Unio pictorum) transplanted in a metal polluted river basin," Aquat. Toxicol. vol. 100, pp. 75-83, 2010.

[14] B. Vuković-Gačić, S. Kolarević, K. Sunjog, J. Tomović, J. KneževićVukčević, M. Paunović and Z. Gačic, "Comparative study of the genotoxic response of freshwater mussels Unio tumidus and Unio pictorum to environmental stress," Hydrobiologia, vol. 735, pp. 221231, 2014.

[15] L. L.Gustafson, M. K. Stoskopf, A. E. Bogan,W. Showers, T. J. Kwak, S. Hanlon and J. F. Levine, "Evaluation of a nonlethal technique for hemolymph collection in Elliptio complanata, a freshwater bivalve (Mollusca: Unionidae)," Dis. Aquat. Organ. vol. 65, pp. 159-165, 2005.

[16] M. Fenech and S. Neville, "Conversion of excision-repairable DNA lesions to micronuclei within one cell cycle in human lympho-cytes," Environ. Mol. Mutagen. vol. 19(1), pp. 27-36, 1992.

[17] Cs. Krifaton, "Development of biomonitoring systems for testing aflatoxin-B1 and zearalenon" $\mathrm{PhD}$ Thesis, Szent István University, Hungary, 2012.

[18] S. A. Hubbard, M. H. L. Green, D. Gatehouse and J. W. Bridges, "The fluctuation test in bacteria" in Handbook of Mutagenicity Test Procedures, B. J. Kilbey, M. Legator, W. Nichols and C. Ramel, Eds. Elsevier Science Publishers, Amsterdam, pp. 141-160, 1984. 
Proc. of the Third Intl. Conf. on Advances in Bio-Informatics and Environmental Engineering - ICABEE 2015 Copyright $@$ Institute of Research Engineers and Doctors, USA .All rights reserved.

ISBN: 978-1-63248-078-1 doi: 10.15224/ 978-1-63248-078-1-69

[19] D. J. Kirkland, "Statistical Evaluation of Mutagenicity Test Data: Recommendations of the U.K. Environmental Mutagen Society," Environ Health Persp Supplements vol. 102(1), pp. 43-47, 1994.

[20] M. Isidori, A. Nardelli, A. Parrella, L. Pascarella and L. Previtera, "A multispecies study to assess the toxic and genotoxic effect of pharmaceuticals: Furosemide and its photoproduct," Chemosphere vol. 63, pp. 785-793, 2006.

[21] B. Jolibois, M. Guerbet and S. Vassal, "Detection of hospital wastewater genotoxicity with the SOS chromotest and Ames fluctuation test," Chemosphere, vol. 51 pp. 539-543, 2003.

[22] B. Jolibois and M. Guerbet, "Hospital Wastewater Genotoxicity," Ann. Occup. Hyg. vol. 50(2), pp. 189-196, 2006.

[23] S. Monarca, C. Zani, S. D. Richardson, A. D. Thruston, M. Moretti, D. Feretti and M. A. Villarini, "New approach to evaluating the toxicity and genotoxicity of disinfected drinking water," Water Res. vol. 38, pp. 3809-3819, 2004.

[24] Y. Ye, J. Weiwei, L. Na, M. Mei, W. Donghong, W. Zijian and R. Kaifeng, "Assessing of genotoxicity of 16 centralized source-waters in China bymeans of the SOS/umu assay and the micronucleus test: Initial identification of the potential genotoxicants by use of a GC/MSmethod and the QSAR Toolbox 3.0." Mut. Res. vol. 763, pp. $36-43,2014$. 